\title{
Polymorphonuclear cell function in rheumatoid arthritis and in Felty's syndrome
}

\author{
G. B. HOWE, J. N. FORDHAM, K. A. BROWN, AND H. L. F. CURREY \\ From the Bone and Joint Research Unit, The London Hospital Medical College, 25-29 Ashfield Street, London \\ E1 $2 A D$
}

SUMMARY Tests for polymorphonuclear cell (PMN) chemotaxis, adherence, and electrophoretic mobility (EPM) were carried out on blood PMN isolated from 27 normal subjects, 16 patients with uncomplicated rheumatoid arthritis (RA), and 9 patients with Felty's syndrome. Chemotaxis was measured by a modification of the Boyden chamber technique, adherence by retention of cells on nylon fibre columns, and EPM in a cylindrical electrophoretic assembly. There was no significant difference between the chemotactic migration of normal and rheumatoid PMN as assessed by the leading front measurement. However, PMN from patients with Felty's syndrome showed significantly reduced chemotaxis $(P<0.001)$. Computerised image analysis showed this impaired migration to be due to an overall reduction in cell motility rather than loss of a subset of cells. Activated serum from patients with RA and Felty's syndrome were as good chemoattractants as activated pooled AB serum. There was no significant difference in the adhesiveness of PMN from normal persons and rheumatoid patients, though PMN from patients with Felty's syndrome did show a trend to lower adhesiveness. Both RA and Felty's syndrome patients had an increase in the proportion of PMN of lower surface charge than controls. Direct correlations were observed between cells of high surface charge and nonadhesiveness.

Studies of the functional state of polymorphonuclear leucocytes (PMN) in rheumatoid arthritis and in Felty's syndrome have produced conflicting results. Mowat and Baum ${ }^{1}$ found PMN chemotaxis to be reduced in rheumatoid patients, and Zivkovic and Baum $^{2}$ showed similar changes in patients with Felty's syndrome. Two more recent studies 34 failed to detect any alteration in the ability of rheumatoid PMN to migrate, but found evidence that serum from some rheumatoid patients reduced chemotaxis as measured by modifications of the Boyden technique. ${ }^{5}$ Some discrepancies between different studies may be technical, for it is now clear that methods which involve counting the cells which reach the lower surface of micropore filters are unreliable. ${ }^{6} 7$

We report here studies of PMN motility employing more recent techniques. Cells from patients with uncomplicated rheumatoid arthritis were compared with cells from patients with Felty's syndrome and from normal controls. Simultaneous tests of PMN adhesiveness and electrophoretic motility, as well as
C1q binding, complement levels (C3, $\mathrm{C} 4$, and $\mathrm{CH} 50)$, rheumatoid factor, and ESR were performed on the same samples of blood.

\section{Materials and methods}

\section{PATIENTS}

Controls were 27 healthy laboratory and clinic staff (16 males and 11 females, aged 21-71 years, mean $40 \cdot 2$ years). 'Uncomplicated' rheumatoid patients were 8 males and 8 females (aged 30-81 years, mean 55.6 years) satisfying the American Rheumatism Association criteria for classical or definite RA. None had clinical splenomegaly or neutropenia. All were taking analgesics and most were also taking nonsteroidal anti-inflammatory drugs. None was receiving corticosteroid or 'slow-acting' drugs. The Felty's syndrome group consisted of 1 male and 8 females (aged $40-80$ years, mean $62 \cdot 8$ years). They were similar to the rheumatoid group, except that all had neutropenia $(175-2140 / \mu l$, mean $1280 / \mu l)$ $\left(0 \cdot 175-2 \cdot 14\right.$, mean $\left.1 \cdot 28, \times 10^{9} / 1\right)$ and all but 1 had an enlarged spleen on clinical examination. No cause for neutropenia or splenomegaly other than 
Felty's syndrome was discovered or suspected among these patients.

\section{CELL PREPARATION}

$8 \mathrm{ml}$ of freshly drawn venous blood containing preservative-free heparin $7 \mathrm{U} / \mathrm{ml}$ was mixed with $0.5 \mathrm{ml}$ of $1.5 \%$ methyl cellulose in saline and allowed to stand in a test-tube at room temperature. After the red cells had sedimented, the PMN-rich buffy coat was drawn off and the cells counted. PMN constituted about $80 \%$ of the nucleated cells present. For certain experiments the PMN were further purified by density centrifugation $(800 \mathrm{~g}$ for 30 minutes) with Lymphoprep (Nyegaard, Oslo), and after washing in phosphate buffered saline, were resuspended in buffered Hanks's balanced salt solution to a concentration of 8400 cells $/ \mu$ l $\left(8.4 \times 10^{9} / 1\right)$ (approximately $85 \% \mathrm{PMN}$ ).

\section{CELL MIGRATION}

A modification of the method employed by Mowat and Baum ${ }^{1}$ was used. PMN enriched buffy layer was centrifuged (Shandon cyto-centrifuge) (200 $g$ for 5 minutes) on to Micropore filters of $3 \mu \mathrm{m}$ pore size (Schleicher and Schull, Dassell, West Germany). The concentration of cells in the enriched buffy coat ranged from 3000 to $18000 / \mu l 3-18 \times 10^{9} / 1$. Additional experiments in which the concentration of cells was manipulated established that variations within this range did not significantly affect motility measurements. The filter with its cell pellet on the upper surface was secured in a modified Sykes-Moore chamber. To assess random motility Hanks's solution buffered to $\mathrm{pH} 7 \cdot 2$ with HEPES was placed in both compartments of the chamber (above and below the filter). For directed motility Hanks's solution containing $33 \%$ serum (either pooled AB or patient's serum) with or without $5 \%$ casein (BDH Chemicals, England) as activator, was placed in the lower compartment.

After incubation at $37^{\circ} \mathrm{C}$ for only 20 minutes (at which time no cells had reached the lower surface of the filter) the filters were fixed overnight in SUSA solution, rinsed in acid alcohol for 2 minutes, then in distilled water for 15 minutes. Next the filters were rendered basic by rinsing in 'blueing agent' ( $2 \mathrm{~g}$ $\mathrm{NaHCO}_{3}, 20 \mathrm{~g} \mathrm{MgSO} / \mathrm{l} / \mathrm{l}$ ) for 2 minutes; dehydrated in absolute alcohol for 3 minutes; cleared in xylene, then mounted in immersion oil (Fractoil, Raymond and Lamb, London).

MEASUREMENTS AND CALCULATIONS

The ' 2 cell leading front' measurement was determined for all subjects by the method of Zigmond and Hirsch. ${ }^{7}$ With a $\times 100$ oil immersion objective 5 random readings were taken from each of the 2 duplicate filters.

COMPUTER-LINKED IMAGE ANALYSIS

The more precise distribution of cells through the filter was measured by computer-linked image analysis (Quantimet 720, Cambridge Instruments, Cambridge, England).

We have described elsewhere the technical details of this application of the Quantimet. ${ }^{8}$ Briefly, a television camera attached to a microscope transmits the microscopic image both to a screen and to a densitometer. A linked computer provides analysis and storage of the output. The microscope is focused on to the upper (starting) surface of a Micropore filter, then moves stepwise down through the filter, recording cell density at $15 \mu \mathrm{m}$ intervals. Automation allows rapid, repeated sampling of random areas, and the mean value at each depth provides a profile of cell density throughout the thickness of the filter. Quantimet studies were carried out in 16 of the controls, 6 'uncomplicated' rheumatoids, and 7 patients with Felty's syndrome.

\section{C $1 \mathrm{Q}$ BINDING}

As a measure of the presence of immune complexes the method of Zubler et al. $^{\mathbf{9}}$ modified by Casali et al. ${ }^{10}$ was used to measure $\mathrm{Clq}$ binding activity.

\section{POLYMORPHONUCLEAR ADHESIVENESS}

A modification of the method of MacGregor et al. ${ }^{11}$ was used. $1 \mathrm{ml}$ of heparinised whole blood was passed through $50 \mathrm{mg}$ of scrubbed nylon fibre (Fenwal Lab, Travenol Labs. Inc, Illinois) packed into $15 \mathrm{~mm}$ of a Pasteur pipette. The difference between the numbers of PMN in the original sample and those recovered in the effluent was taken to indicate the number of cells adhering. Tests were performed in triplicate between 60 and 90 minutes after venesection.

\section{ELECTROPHORETIC MOBILITY}

Measurement of the electrophoretic mobility (EPM) of PMNs was performed in a cylindrical electrophoretic assembly as described previously. ${ }^{12}$ For each analysis 100 cells were scored and their EPMs expressed as $\mu \mathrm{m} \cdot \mathrm{cm} \cdot \mathrm{s}^{-1} \cdot \mathrm{v}^{-1}$. Probit analysis of the EPMs was used to test for departures from the normal distribution.

\section{Results}

\section{MOTILITY ST UDIES}

Fig. 1 summarises motility experiments using buffy layer preparations and the leading front method of measurement. 


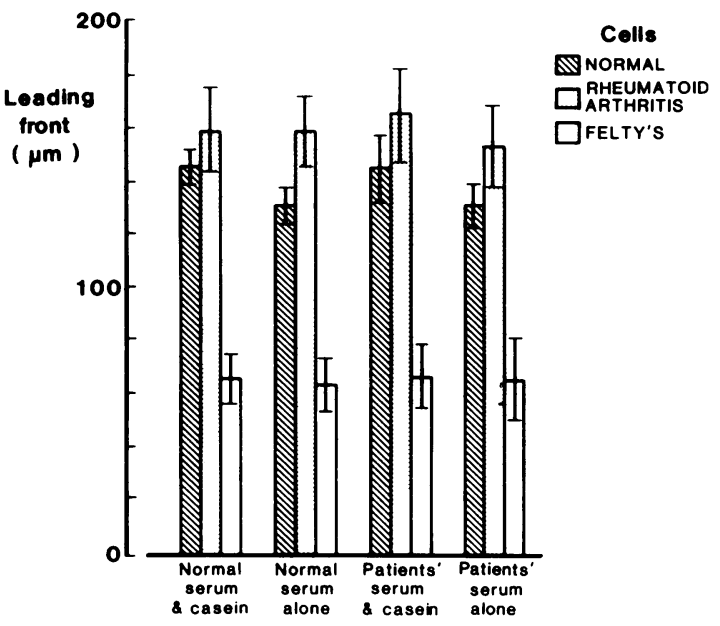

Fig. $1 P M N$ migration measured by the leading front method. Vertical lines indicate the standard error of the mean.

With normal serum activated by casein as attractant, the motility of uncomplicated rheumatoid cells was not significantly different from that of normal persons. By contrast, cells from cases of Felty's syndrome travelled less than half the distance covered by normal and rheumatoid cells (65 vs. 145 and $160 \mu \mathrm{m}, \mathrm{p}<0.001)$. Substitution of the normal serum with patients' serum (to give an autologous combination in the case of patients' cells) showed that serum from both uncomplicated rheumatoid and Felty sera performed as well as normal serum. Thus, no latent serum inhibitor of chemotaxis ${ }^{3}$ was demonstrated.

The leading front technique did not allow us to determine whether the gross reduction in motility of PMN from Felty's patients represented an overall 'slowing' of the whole cell population, or whether, for example, a fast moving subset of cells was missing in these patients. For this we turned to computer linked image analysis employing the Quantimet (see 'Methods').

Fig. 2 shows the cell density profiles for the 3 groups measured by the Quantimet. Again, cells from normal persons and from rheumatoids are similar, while the Felty's cells are clearly much 'slower.' These same data can be used to derive cumulative percentile distributions of cells. Comparison of the cumulative percentile and cell distributions between the 3 groups tested shows similarity between the uncomplicated rheumatoids and normals, while Felty's cells reached only half as far. This was an overall slowing without any suggestion of depletion or altered function in a subset. A more detailed discussion concerning this appears elsewhere. ${ }^{8}$

POLYMORPHONUCLEAR CELL ADHESIVENESS The percentage of PMN adherent to nylon fibre columns is shown in Table 1. Although there tended to be fewer adherent PMN in the Felty's group than in the rheumatoid and normal subjects, this difference did not reach significance.

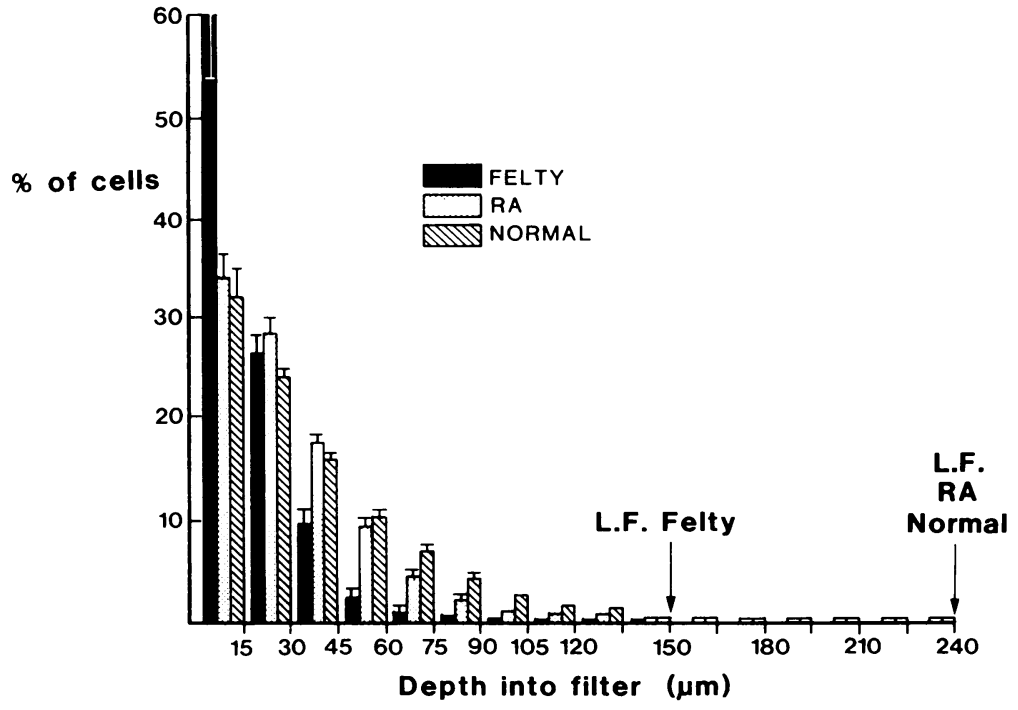

Fig. 2 Mean cell density profile within filters after 20 minutes' directed migration. Measurements by computerised image analysis (Quantimet). Arrows indicate leading front ( $L F$ ) measurements obtained by direct microscopy. Vertical lines indicate the standard error of the mean. 
Table 1 Adherence of PMN to nylon fibre columns

\begin{tabular}{ll}
\hline & Mean $\% \pm$ standard deviation \\
\hline Normals & $36 \cdot 3 \pm 14 \cdot 8$ \\
RA & $43 \cdot 0 \pm 22 \cdot 2$ \\
Felty's syndrome & $25 \cdot 2 \pm 14 \cdot 1$ \\
\hline
\end{tabular}

Table 2 Electrophoretic distribution of PMN (\%)

\begin{tabular}{llll}
\hline & Distribution & $\begin{array}{l}\text { Distribution } \\
\text { II }\end{array}$ & $\begin{array}{l}\text { Distribution } \\
\text { III }\end{array}$ \\
\hline Normals & $76 \pm 11$ & $17 \pm 9$ & $7 \pm 7$ \\
RA & $47 \pm 22$ & $42 \pm 13$ & $11 \pm 13$ \\
Felty's syndrome & $56 \pm 18$ & $26 \pm 14$ & $18 \pm 17$ \\
\hline
\end{tabular}

$\pm=$ Standard deviation from the mean.

Table 3 Correlations between EPM distributions I and II and nonadherent and adherent PMN

\begin{tabular}{llll}
\hline & Normals & RA & $\begin{array}{l}\text { Felty's } \\
\text { syndrome }\end{array}$ \\
\hline $\begin{array}{l}\text { Nos. adherent vs. nos EPM II } \\
\text { Nos. non-adherent vs. nos. }\end{array}$ & +0.9174 & +0.7140 & +0.7878 \\
EPM I & +0.6433 & +0.7994 & +0.6935 \\
\hline
\end{tabular}

Numbers are correlation coefficients.

ELECTROPHORETIC MOBILITY ANALYSIS OF POLYMORPHONUCLEAR CELLS

Probit analysis of the EPM values of PMN from all subjects studied suggested distributions into 3 groups whose EPM ranged from 0.91 to 0.88 $\mu \mathrm{m} . \mathrm{cm} . \mathrm{s}^{-1} . \mathrm{v}^{-1}$ (distribution I), 0.85 to $0.82 \mu \mathrm{m} . \mathrm{cm}$. $\mathrm{s}^{-1} \cdot \mathrm{v}^{-1}$ (distribution II), and $<0.80 \mu \mathrm{m} \cdot \mathrm{cms}^{-1} \cdot \mathrm{v}^{-1}$ (distribution III). The percentage distribution of PMN in the 3 groups of subjects is shown in Table 2.

PMN in distribution $I$ are cells which had the highest net negative surface charge. There was a significant decrease in the number of PMN from rheumatoid $(p<0.001)$ and Felty's syndrome $(p<0.05)$ patients in distribution I compared with normal PMN. This was due to more of the PMN from both rheumatoid and Felty's syndrome patients having a lower net negative surface charge.

From Table 3 it can be seen that there was a good correlation between the number of cells in distribution $I$ and the number of nonadherent PMN, and between the number of cells in distribution II and the number of adherent PMN.

\section{PATIENT CHARACTERISTICS AND OTHER} LABORATORY TESTS

Analysis of the data from the various tests applied revealed no differences attributable to age, sex, length, or severity of disease or drug intake, nor (among the Felty's group) to propensity to infection-but the numbers are small. Also, there was no correlation between the results on the one hand of the tests of chemotaxis, EPM, and adherence, and on the other hand the laboratory values for ESR, C1q binding, rheumatoid factor titre, or complement levels.

\section{Discussion}

This study showed no significant difference between the chemotactic migration of blood PMN from uncomplicated rheumatoid patients and those from controls. However, the chemotactic migration of blood PMN from patients with Felty's syndrome was significantly reduced. There was no statistical difference in the adherent properties of PMN from the 3 groups of subjects studied, though there were more cells with a low surface charge in the blood of uncomplicated RA and Felty's syndrome than in normal subjects.

Our failure to demonstrate an impairment of chemotactic migration by RA PMN, as reported by Mowat and Baum, ${ }^{1}$ supports the findings of Hanlon et al. $^{3}$ and Kemp et al. ${ }^{14}$ Mowat and Baum ${ }^{1}$ used PMN which were not washed prior to their chemotactic migration, and therefore the observed chemotactic defect in rheumatoid PMN could have been due either to an intrinsic defect of the PMN or to humoral factors present in the serum.

Several workers have described inhibition of chemotactic migration of normal PMN after suspension of the cells in rheumatoid sera, in contrast to the unaltered migration of normal PMN after

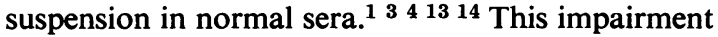
of chemotaxis has been attributed to phagocytosis by circulating PMN of immune complexes present in RA sera ${ }^{15}$ and to the adherence of immune complexes to the PMN surface. ${ }^{14} \mathrm{Kemp}$ et al. ${ }^{14}$ found a significant correlation between the extent of random PMN migration inhibition and the level of Clq binding immune complexes. In a recent study ${ }^{13}$ it was suggested that the inhibitory activity of rheumatoid sera was due to the presence of a serum inhibitor of chemotaxis. In a small number of experiments, not reported in this paper, we found that incubation of normal PMN in rheumatoid sera did not produce a consistent impairment of chemotactic migration. Whether or not these fluctuating results were a consequence of testing serum samples from patients with a wide spectrum of disease activity is being investigated.

An important factor that may explain the discrepancy in results from this study and that of Mowat and Baum ${ }^{1}$ is the variation in methodology In the chemotactic assay of Mowat and Baum ${ }^{1}$ migration was quantitated by counting the number 
of cells present on the lower surface of the filters, a technique which we and others ${ }^{6,7}$ have found to be inaccurate. However, the same technique was used by Zivkovic and Baum ${ }^{2}$ to demonstrate that the chemotaxis of PMN from patients with Felty's syndrome was significantly inhibited from that of normal persons, a finding supported by our present study.

Our Quantimet analysis suggests that the impairment of Felty's PMN chemotactic migration was due to an overall reduction in cell motility rather than a loss of a subset of cells, and that this impairment was predominantly a cellular defect. Although our data point to there being an intrinsic reduction in Felty's PMN motility, this does not preclude the possibility of additional migration inhibition by humoral factors.

The in-vivo adhesion of PMN to vascular endothelium is believed to be reflected by the adherence of PMN to nylon fibre columns. Using such columns MacGregor ${ }^{16}$ showed that rheumatoid PMN were more adherent than normals, though the extent of adherence was related to the activity of disease and aspirin therapy. ${ }^{17}$ Our inability to demonstrate a difference in the adherence of normal, rheumatoid, and Felty's PMN to nylon fibre columns was probably due to very few of our selected patients receiving aspirin therapy and also the varying grades of disease activity.

Probit analysis of the EPM of PMN suggested 3 distributions. Patients with rheumatoid arthritis and Felty's syndrome had more cells of a lower surface charge than normals. These results are in agreement with a previous observation which showed an increase in cells of low EPM in RA when compared with blood PMN from healthy controls. ${ }^{12}$

The immature and functionally impotent bone marrow PMN possesses a greater net negative surface charge distinct from that of the circulating PMN, which expresses chemotactic and phagocytic activity, ${ }^{18}$ implying that surface charge may be related to cell function.

The demonstration that phagocytosis by rat macrophages was enhanced by polyelectrolytes which lowered their EPM ${ }^{19}$ and that certain chemotactic factors lowered the EPM of $\mathrm{PMN}^{20}$ raises the possibility that a decrease in surface charge may be an important factor in the margination and diapedesis of PMN in inflammation. If so, this fits well with the suggestion that an increase in the margination of circulatory PMN is the mechanism for the neutropenia associated with Felty's syndrome. ${ }^{21}$

In this study the number of PMN with high EPM correlated with nonadhesiveness, while the numbers of lower EPM cells correlated with adhesiveness.
Further, we have observed that the passage of rheumatoid PMN through nylon fibre columns results in retention of cells with low EPM (unpublished findings). From these results we would have expected there to be a difference in the adherent properties of rheumatoid and normal PMN. The failure to demonstrate such a difference may be a result of the different sensitivities of the 2 techniques. Experiments are being initiated to separate the 3 electrophoretic distributions by preparative electrophoresis in order to investigate their separate functional properties.

G.B.H. was in receipt of a Michael Mason travelling fellowship from the Arthritis and Rheumatism Council. The Council also provided general financial support.

\section{References}

1 Mowat A G, Baum J. Chemotaxis of polymorphonuclear leucocytes from patients with rheumatoid arthritis. J Clin Invest $1971 ; 50: 2541-4$.

2 Zivkovic M, Baum J. Chemotaxis of polymorphonuclear leucocytes from patients with systemic lupus erythematosus and Felty's syndrome. Immunol Commun 1972; 1 : $39-49$.

3 Hanlon A N, Panayi G S, Laurent R. Defective polymorphonuclear chemotaxis in rheumatoid arthritis associated with a serum inhibitor. Ann Rheum Dis 1980; 39: 68-74.

4 Walker J R, James R N, Smith M J H. Directed migration of evaluating polymorphonuclear leucocytes in patients with rheumatoid arthritis: a defect in the plasma. Ann Rheum Dis 1979; 38: 215-8.

5 Boyden S. The chemotactic effect of mixtures of antibody and antigen on polymorphonuclear leucocytes. $J$ Exp Med 1962; 115: 453-66.

6 Maderazo E, Woronick C. Micropore filter assay of human granulocyte locomotion: Problems and solutions. Clin Immunol Immunopathol 1978; 11 : 196-211.

7 Zigmond S, Hirsch J. Leucocyte locomotion and chemotaxis (new method of evaluation and demonstration of a cell-derived chemotactic factor). J Exp Med 1973; 137: 387-410.

8 Howe G B, Swettenham K V, Currey H L F. Polymorphonuclear motility: measurement of computer-linked image analysis. Blood in press.

9 Zubler R H, Nydegger U, Perrin L H, et al. Circulating and intra-articular immune complexes in patients with rheumatoid arthritis. Correlation of ${ }^{125} \mathrm{I}-\mathrm{Clq}$ binding activity with clinical and biological features of the diseases. J Clin Invest 1976; 57: 1308-19.

10 Casali P, Bossus A, Carpentier N A, Lambert P H. Solid phase enzyme immunoassay or radioimmunoassay for the detection of immune complexes based on their recognition by conglutinin: conglutinin-binding test. A comparative study with ${ }^{125} \mathrm{I}$-labelled $\mathrm{Clq}$ binding and Raji-cell RA tests. Clin Exp Immunol 1977; 29: 342-54.

11 MacGregor R R, Spangnuolo P J, Lentrek A L. Inhibition of granulocyte adherence by ethanol, prednisone, and aspirin measured with an assay system. $N$ Engl J Med 1974; 291: 642-6.

12 Brown K A, Collins A J, Holborow E J. Cell electrophonoretic analysis of lymphocytes and polymorphonuclear cells from patients with rheumatoid arthritis. Lancet 1977; i: 114-7. 
13 Beeuwkes H, Bijlsma A. Reduced chemotaxis of polymorphonuclear leukocytes in sera from patients with rheumatoid arthritis. Antonie van Leeuwenhoek 1974; 40: 233-9.

14 Kemp A S, Roberts-Thompson P, Neoh S H, Brown S. Inhibition of neutrophil migration by sera from patients with rheumatoid arthritis. Clin Exp Immunol 1979; 36: 423-7.

15 Roberts-Thompson P J, Hazleman B L, Barnett I G, Maclennan I C M, Mowat A G. Factors relating to circulating immune complexes in rheumatoid arthritis. Ann Rheum Dis 1976; 35: 314-20.

16 MacGregor R R, Macarak E J, Kefalides N A. Comparative adherence of granulocytes to endothelial monolayers and nylon fibre. J Clin Invest 1978; 61 : 697-702.
17 MacGregor R R. The effect of anti-inflammatory agents and inflammation of granulocyte adherence. Am J Med 1976; 61 : 597-607.

18 Lichtman M A, Weed R I. Alteration of the cell periphery during granulocyte maturation: relationship to cell function. Blood 1972; 39: 301-16.

19 Nagura H, Asai J, Katsumata Y, Kojima K. Role of electric surface charge of cell membrane in phagocytosis. Acta Pathol Jpn 1973; 23: 279-90.

20 Gallin J I, Curocher J R, Kaplan A P. Interaction of leukocyte chemotactic factors with the cell surface. I: Chemotactic factor-induced changes in human granulocyte surface charge. J Clin Invest 1975 ; 55 : 967-74.

21 Vincent P C, Levi J A, MaQueen A. The mechanism of neutropenia in Felty's syndrome. Br J Haematol 1974; 27: 463-75. 